\title{
MORPHOPHYSIOLOGICAL DEVELOPMENT OF Tabeluia serratifolia Vahl Nich. SEEDS
}

\author{
Maria Laene Moreira de Carvalho ${ }^{1 *}$; Marcela Carlota Nery ${ }^{1}$; Luciana Magda de Oliveira ${ }^{1}$; \\ Henk W. M. Hilhorst ${ }^{2}$; Renato Mendes Guimarães ${ }^{1}$ \\ ${ }^{1}$ UFLA - Depto. de Agricultura, C.P. 3037 - 37200-000 - Lavras, MG - Brasil. \\ ${ }^{2}$ Wageninen University - Lab. of Plant Physiology - P.O. Box 9101 - 6700 HB -Wageningen - The Netherlands. \\ *Corresponding author 〈mlaenemc@ufla.br>
}

\begin{abstract}
Tabebuia serratifolia is used for the reforestation of degraded areas. Despite protection by law for permanent preservation, the species is in danger of extinction due to improper exploitation. With the objective to aid preservation and long term storage of the species we evaluated morphophysiological alterations of $T$. serratifolia seeds during the maturation process in order to identify markers that can be used for harvesting and storage. Fruits were collected at anthesis and seven developmental stages from trees growing in Lavras, state of Minas Gerais, Brazil. At each harvest, fruits and seeds were evaluated for color and size, moisture content, dry matter, internal morphology (by X-ray analysis), germination parameters (in vitro and ex vitro), as well as sugar and polyphenol content and heat resistant proteins. During the maturation process the initially green fruits changed to a brownish color and grew from a length of 7 to $18 \mathrm{~cm}$; cracks appeared at the beginning of seed dispersal. The seed color varied from leaf-green to brownish and the length from 1 to $3 \mathrm{~cm}$. The first indicatior of physiological maturity should be observed at 39 days post-anthesis, when variations the color and size of both fruits and seeds were observed. Increase in the moisture content, dry matter and germination, percentage of seeds and embryos in vitro, as well as a reduction in sugar content and LEA proteins were also observed. The physiological maturity of $T$. serratifolia seeds was reached 53 days after anthesis, coinciding with a maximum of dry matter accumulation and germination (and index of germination speed ex vitro), decrease in phenol levels, higher intensity of heat-resistant protein bands and the beginning of fruit opening.
\end{abstract}

Key words: forest seeds, maturation, seed quality, preservation

\section{DESENVOLVIMENTO MORFOFISIOLÓGICO DE SEMENTES DE IPÊ-AMARELO (Tabeluia serratifolia Vahl Nich.)}

RESUMO: Tabebuia serratifolia é utilizada no reflorestamento de áreas degradadas. Devido à sua exploração indevida, encontra-se em perigo de extinção, apesar de protegida por lei para preservação permanente. Foram investigadas as alterações morfofisiológicas de sementes de ipê-amarelo ao longo do desenvolvimento, para fins de auxiliar a conservação dessa espécie. Os frutos foram coletados a partir da antese, em sete estádios de desenvolvimento, em árvores localizadas na região de Lavras, MG, Brasil. Em cada coleta, as sementes foram submetidas às análises radiográficas e microscópicas, avaliando-se as colorações e tamanho, o grau de umidade e matéria seca tanto dos frutos como das sementes, a germinação in vitro e ex vitro, bem como os teores de açúcares, polifenóis e proteínas resistentes ao calor. Durante o desenvolvimento os frutos que inicialmente eram verdes passaram para amarronzados e o comprimento de 7 para $18 \mathrm{~cm}$, apresentando fendas que iniciam a dispersão de suas sementes. As sementes tiveram sua cor variando de verde-folha a amarronzado e comprimento de 1 a $3 \mathrm{~cm}$. As alterações iniciais indicativas da maturidade fisiológica de sementes de ipê-amarelo ocorreram a partir dos 39 dias após a antese, quando ocorreram variações na coloração, no tamanho de frutos e sementes e na visualização das estruturas internas, além de aumentos nos teores de água, matéria seca e porcentagem de germinação de sementes e embriões e ainda, redução dos açúcares redutores e das proteínas resistentes ao calor. A maturidade fisiológica das sementes de Tabebuia serratifolia é alcançada aos 53 dias após a antese, coincidindo com o acúmulo máximo de matéria seca, germinação (e índice de velocidade de germinação), além de decréscimo no teor de polifenóis e maior intensidade de bandas inidicadoras de proteínas resistentes ao calor e o início da abertura dos frutos.

Palavras-chave: sementes florestais, maturação, qualidade de sementes, preservação 


\section{INTRODUCTION}

The species Tabebuia serratifolia (Vahl) Nicholson Gomes ex DC. (one of the Brazilian "ipêsamarelos") is a tree species of the Bignoniaceae, normally used in urban arborisation, and can be found in Bolivia, Colombia, Equador, Guyana, French-Guyana Francesa, Peru, Surinam, Trinidad \& Tobago, Venezuela and almost everywhere in Brazil. It is also indicated for studies on the recovery of degraded areas and for medicinal purposes (Rodrigues et al., 2004; Awale et al., 2005).

The propagation of $T$. serratifolia occurs through seeds, which present problems of germination and conservation (Oliveira, 2004). The seed germination is extremely variable and may differ among seed lots, according to their different origins, collections and processing systems and storage methods, which can result in considerable losses in seedling production from forest nurseries (Maeda \& Matthes, 1984; Figliolia et al., 1988; Kageyama et al., 1992). The germination process may be influenced by seed formation conditions while the production conditions, including climate, phytosanitation and physiological aspects determine the seed lot quality (Barbedo \& Cicero, 2000).

The morphophysiological alterations that occur during seed formation are marked by events inherent to each species. Among the events, moisture content and dry matter accumulation have been suggested as indicators of physiological seed maturity since the moisture content changes continuously during dry matter accumulation, which allows a more detailed developmental control (Astarita et al., 2003; Mai-Hong et al., 2006; Shah et al., 2006).

Investigations that relate seed quality with maturity have demonstrated that the greatest seed vigor and highest germination degree occur when the moisture content is high and dry matter accumulation highest (Leprince et al., 1990; Tekrony \& Hunter, 1995; Ajayi \& Fakorede, 2000). Alterations in the patterns of gene expression represented by the accumulation of specific mRNAs (Leprince et al., 1990; Vertucci \& Farrant, 1995; Sun et al., 2002; Wise, 2003) or of chemical components (Hoekstra et al., 2001; Gurusinghe \& Bradford, 2001; Buitink et al., 2002) can also indicate the seed quality during the development.

Morphological aspects such as internal and external fruit and seed alterations (Liu et al., 1993) and changes in size and color (Shah et al., 2006) are also fundamental for the establishment of harvest-related procedures, conservation and reproduction of the species.
The seed development of $T$. serratifolia and its main morphophysiological alterations that occur from the formation until physiological maturity, were assessed to provide information to identify patterns and markers useful to acess high quality seeds to produce and conservancy of this important specie.

\section{MATERIAL AND METHODS}

\section{Plant material}

Seeds and fruits were obtained from a population of 63 trees, in Lavras (altitude $919 \mathrm{~m}$ asl, 21 ${ }^{\circ} 14^{\prime}$ S, $45^{\circ} 00^{\prime}$ W), state of Minas Gerais, Brazil. Fruits were sampled weekly from 15 randomly chosen trees at 10 , $18,25,32,39,47$ days post anthesis (DPA), and seeds until 53 days, after anthesis. Fruits opened at 47 DPA. The collected fruits were selected according to health aspect and developmental stage, then washed under tap water and immersed in hypochlorite solution $(1 \%$ active chlorine) for $5 \mathrm{~min}$, washed again under tap water for $3 \mathrm{~min}$ and dried on paper towel (Nobre, 1994).

\section{Determination of color and size}

The collected fruits were analyzed for color (CIELAB color system), using a Minolta Chromameter CR- 300. The seeds were removed by longitudinal parting and quick torsion of the fruits. Seed color was determined by comparing the seeds with the Munsell ${ }^{\circledR}$ Color Charts for Plant Tissues and the fruit and seed sizes were measured with a graded ruler.

\section{Determination of fruit and seed moisture content}

Moisture content was determined using an oven at $103^{\circ} \mathrm{C} \pm 2^{\circ} \mathrm{C}$ for 17 hours (ISTA, 2004), with four replicates of five fruits cut in pieces of $1.5 \mathrm{~cm}$. Four replicates of one gram were used for the seeds. The results were expressed in percentage, based on fresh weight.

\section{Determination of fruit and seed dry matter}

The fruits were cut in $0.5 \mathrm{~cm}$ pieces and four replicates of one gram of seeds were dried in an oven with ventilation at $60^{\circ} \mathrm{C}$ for 24 hours (ISTA, 2004).

\section{Radiographic analysis}

The internal morphology of the seeds in the different development stages was evaluated by a 43855 A X-Ray System (Faxitron-HP). Seeds were placed on transparent slides, fixed with double-sided scotch tape and subjected to radiation of $55 \mathrm{kV}$ intensity during 25 seconds (Oliveira, 2004).

\section{Embryo in vitro cultivation}

Embryos were manually extracted and disinfected with $70 \%$ alcohol for $1 \mathrm{~min}$ and with $2 \%$ sodium hypochlorite for $2 \mathrm{~min}$, then washed three times 
in distilled and autoclaved water. The three-fold washing in sterile water was repeated before inoculation after which the embryos were bathed in a $2 \%$ systemic fungicide (carbendazim) solution for $2 \mathrm{~min}$. The isolated embryos were maintained in Murashige \& Skoog (MS) in vitro culture medium (Murashige \& Skoog, 1962) and in other Wood Plant Medium (WPM) medium (Lloyd \& McCown, 1980), with addition of $2 \% \mathrm{GA}_{3}$ (gibberellic acid), activated carbon and PVP (polyvinylpirrolidone), with 3\% saccharose and $0.6 \%$ agar. The $\mathrm{pH}$ was adjusted to 5.8 before autoclaving. After inoculation, the flasks with the embryos were kept in a growth chamber at $27 \pm 2^{\circ} \mathrm{C}$ and a light intensity of $13 \mu \mathrm{mol} \mathrm{s}^{-1} \mathrm{~m}^{-2}$. Daily assessment included root elongation of embryos, number of normal seedlings 14 days after inoculation (first count of embryo germination) and 28 days after inoculation (embryo germinability), as well as the index of embryo germination speed (Maguire, 1962).

\section{Germination ex vitro}

Three methods were adopted to test germination ex vitro: without surface sterilisation (control), with sodium hypochlorite (2\% active chlorine) for 3 min and treatment with systemic fungicide (Carbendazim - 2\%) for $2 \mathrm{~min}$. The test was performed with four replicates of 50 seeds at $30^{\circ} \mathrm{C}$, under constant light (ISTA, 2004). The evaluations of root protrusion and percentage of normal seedlings took place 14 days (first count) and 28 days after sowing (final count). The index of germination speed (IGS) was evaluated together with the germination test; counts were carried out daily from the day the first normal seedlings appeared in the germination test.

\section{Polyphenol content}

Polyphenols were extracted by the method of Goldstein \& Wail (Goldstein \& Wail, 1963) [26], using $80 \%$ methanol in water and determined according to the method of Follin-Denis, described by the AOAC (AOAC, 1990).

\section{Sugar content}

For the sugar determinations, glucose, saccharose, raffinose and stachyose were separated by highperformance liquid chromatography (HPLC, Shimadzu) according to Bernal-Lugo and Leopold (Bernal-Lugo \& Leolpold, 1992) in a Dextrapak cartridge column (8 $\times 100 \mathrm{~mm}$; Waters Corp, Milford, MA) and analyzed in a Waters 410 refraction index detector, sensitivity $32 \times 20$, positive polarity, using just duplicate of treatments.

\section{Determination of heat-resistant proteins}

For the determination of heat-resistant proteins sodium dodecyl sulphate polyacrylamide gel electro- phoresis (SDS-PAGE) was run at a constant voltage of $100 \mathrm{~V}$ for 6 hours (12.5\% resolving gel and 6\% stacking gel). Before sample loading, the sample tubes containing $100 \mu \mathrm{L}$ extract (seeds knead) $+57 \mu \mathrm{L}$ sample buffer solution were maintained in a boiling water bath for 5 min (Blackman et al., 1991). The gels were stained with $0.05 \%$ Coomassie blue for 18 hours and diffusion-destained in $10 \%\left(\mathrm{v} \mathrm{v}^{-1}\right)$ acetic acid solution (Alfenas et al., 1991).

\section{Statistical analysis}

The experiments were set up according to a completely randomized design. The data were first tested for normality of residue and homocedasticity of variances. The moisture content and dry matter date were transformed by the Neperian logarithm (e) and the germination data transformed in $\arcsin \sqrt{x / 100}$. The means of the treatments were compared by Tukey's test at 5\% probability and the data of the counts evaluated by the polynomial regression analysis, using the program PROC GLM of the software package SAS ${ }^{\circledR}$ (SAS, 1990) for statistics.

\section{RESULTS AND DISCUSSION}

During the period of $T$. serratifolia fruit and seed formation the mean daily temperature varied from $18.5^{\circ} \mathrm{C}$ (47 DPA) to $23.0^{\circ} \mathrm{C}$ (39 DPA) and the relative air humidity from $48 \%$ (25 DPA) to $72 \%$ (47 DPA). These conditions allowed seed development and collection without apparent climate stress.

Variations in the fruit and seed color and size were observed during the seed formation period (Table 1) characterizing the different stages of $T$. serratifolia seed development. Significant variations in the fruit color $(\Delta \mathrm{E})$ occurred at 25,39 and $47 \mathrm{DPA}$. The fruit color changed from green to bluish to brownish at the end of the evaluation period, which coincided with fruit opening when longitudinal cracks appeared. Color alterations on fruits of the genus Tabebuia have been associated with the ideal harvest time. For $T$. impetiginosa, the fruit color varies from dark green with large purplish spots to green with little purplish dots (Gemaque et al., 2002) while the color of $T$. avellanedae fruits changes to yellow-brownish at maturation (Barbosa et al., 1992). The seed color varied from leaf-green in the first development stage to brownish at 53 DPA.

The fruit length increased over the course of development from $7 \mathrm{~cm}$ just after fertilization up to a maximal size of $18 \mathrm{~cm}$ at $32 \mathrm{DPA}$, with no variation thereafter. Similar results, regarding increases in fruit size during the stages prior to maturation were observed in Mangifera indica, which is also a member of the Anarcadiaceae (Wang \& Fu, 1991). Fruit length 
Table 1 - Color $\left(\Delta \mathrm{E}^{1}\right)$ and length of Tabebuia serratifolia fruits and seeds during seed development, expressed as days postanthesis (DPA).

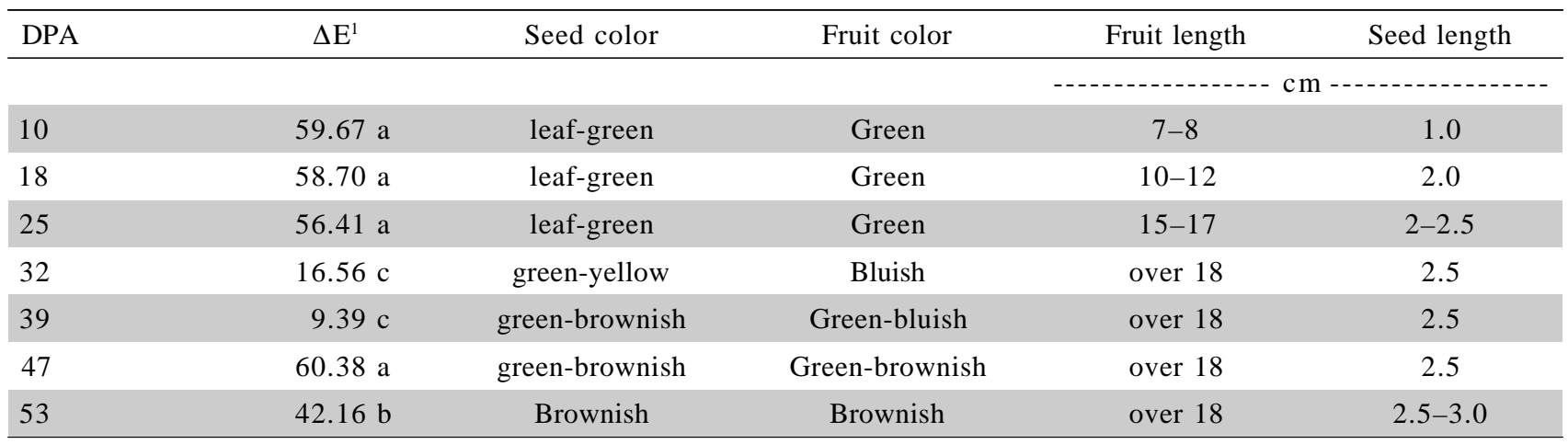

${ }^{1}$ Means followed by the same letter in a column did not differ (Tukey's test $p<0.05$ ).

and width are therefore inadequate parameters to support the determination of physiological seed maturity.

The maximal seed length was $3.0 \mathrm{~cm}(53$ DPA). The values for width did not exceed $1 \mathrm{~cm}$ during the different developmental stages (Table 1). This seed growth pattern was similar to the one described by Carvalho \& Nakagawa (2000) who reported that the seeds generally increased quickly in size, reaching a maximum in a relatively short time as compared to the total duration of the maturation period. This relatively high speed at which seeds attain maximum size is possibly due to the need of seeds to maintain a high moisture content during the stage of most intense dry matter accumulation.

The moisture content of fruits and seeds was maintained at approximately $90 \%$ until 47 DPA (Figure 1) after which, a reduction in the seed moisture content to approximately $30 \%$ at 53 DPA was observed.

This pattern in fruit and seed moisture content during maturation has been observed for seeds of numerous species, including Mimusops elengi (Sapotaceae [Mai-Hong ET AL., 2006]) and Pyracantha crenulata (Rosaceae) (Shah et al., 2006). The highest dry matter values were observed at 47 DPA for the fruits and at 53 DPA for the seeds (Figure 2). Some authors consider the seed moisture content and dry matter effective indexes in the determination of the physiological seed maturity of species, such as Tabebuia avellanedae (Barbosa et al., 1992).

Figure 3 summarizes the radiographic analysis of $T$. serratifolia seeds at the different developmental stages. At 10 DPA, the seeds were still in their early formation stage. At $18 \mathrm{DPA}$, their internal structures were not yet fully formed and the external structures (the integuments) were not thick yet. At 25 and 32 DPA, the internal seed structure still had a horizontal longish shape, but were capable to reach $48 \%$ and $85 \%$ of germination in vitro, respectively. Only at 39 DPA, the internal structures seemed to be fully formed,

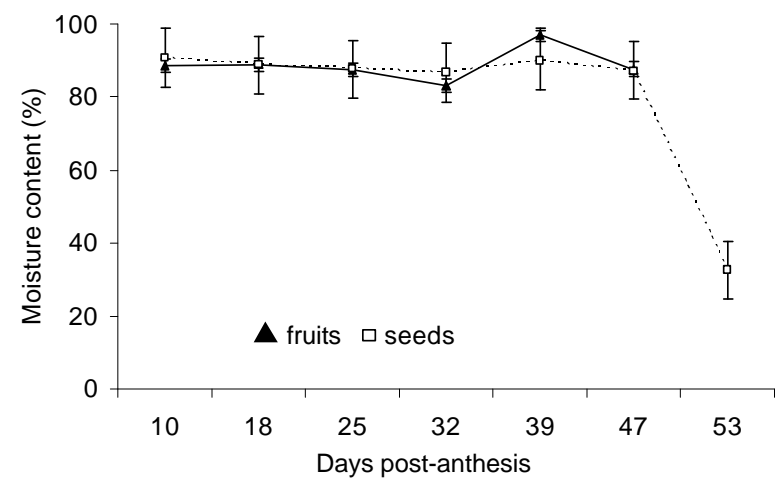

Figure 1 - Moisture content (fresh weight basis) of Tabebuia serratifolia fruits $(10,18,25,32,39$ and at dehiscence at 47 DPA) and seeds $(10,18,25,32,39,47$, and 53 DPA) during development. Vertical bars indicate standard deviation.

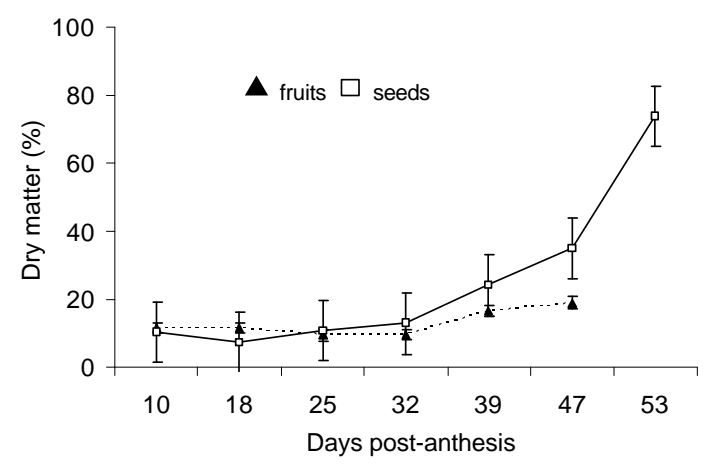

Figure 2 - Dry matter of fruit (10, 18, 25, 32, 39 and at dehiscence at $47 \mathrm{DPA}$ and seed $(10,18,25,32,39,47$, and 53 DPA) of Tabebuia serratifolia during development. Vertical bars indicate standard deviation.

which coincided with $100 \%$ germination in vitro. Seeds at this point generated the highest percentage of normal seedlings by in vitro cultivation. The internal structures were best visualized at 53 DPA, probably due to the dry matter accumulation at this developmental stage, combining lower moisture content and clear differentiation of the tissues with different den- 

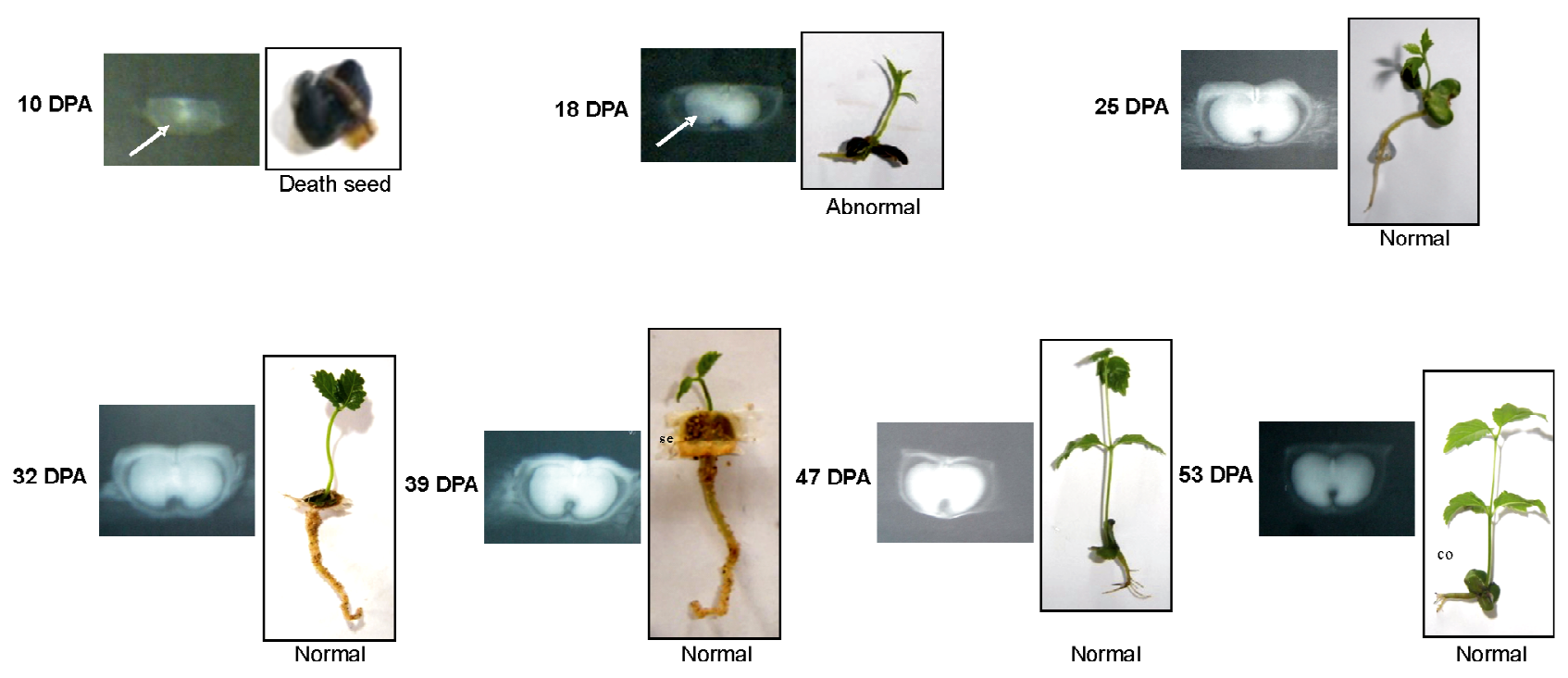

Figure 3 - Radiographic images of T. serratifolia seeds and seedlings during in vitro cultivation (normal and abnormal seedling), during development. The arrow indicates developing tissues. se = seed; le = leaf; co = cotyledon.
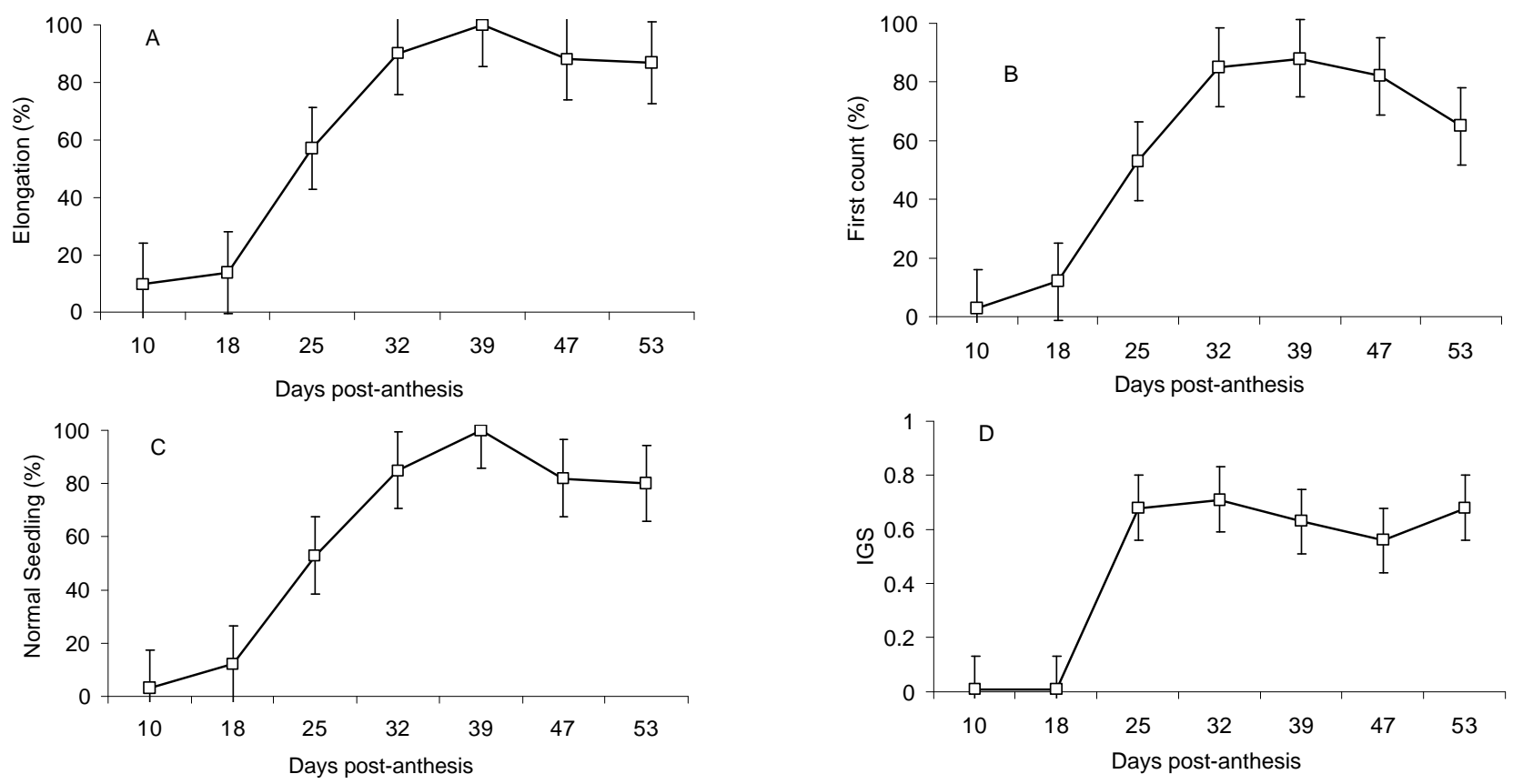

Figure 4 - Root elongation of embryos (A); normal seedlings (first count) (B); normal seedling (C) and index of germination speed (IGS) (D) in the MS culture medium of Tabebuia serratifolia embryos during development. Vertical bars indicate standard deviations.

sities. In some species the radiographic analysis allows (in function of the development stage and the morphology of the embryos) an estimation of the seed lots physiological quality, according to results obtained for T. serratifolia and T. impetiginosa (Oliveira, 2004).

The in vitro growth of $T$. serratifolia embryos during development showed no significant differences between MS and WPM culture media. Increments in embryo growth started at 10 DPA. The values of root elongation and percent normal seedlings after 14 days of embryo inoculation (first count) and embryo germinability reached their maximum at 39 DPA. The highest embryo germination speed was reached at 32 DPA (Figure 4). Thereafter, decreases were observed for root elongation and percent normal seedlings (first count), embryo germinability and index of in vitro germination speed. Abscisic acid (ABA) may be involved in the induction of dormancy in the embryos during the seed tissue formation and explain the observed decrease in embryo germination (Bewley \& Black, 1994). 
The ex vitro seed germination of $T$. serratifolia became apparent from 32 DPA for all parameters evaluated. The maximum values of root protrusion (first count, final count and index of germination speed) were attained at 53 DPA (Figure 5). Within this period of development, the values of dry matter accumulation (Figure 2) and fruit opening were also high. A similar performance of maximum germination associated with the period of fruit opening was reported for Tabebuia impetiginosa (Gemaque et al., 2002) and Tabebuia avellanedae seeds (Barbosa et al., 1992), which present maximum germination and dry matter values and reduced values of moisture content at the moment of dehiscence and seed dispersion.

Differences in the germination percentage of the non-disinfested seeds (control) and seeds disinfested with a systemic fungicide (Carbendazim) were not significant (data not shown). However the treatment with sodium hypochlorite however led to a reduction in the germination percentage. This was probably due to a phytotoxic effect, since in the initial development stages, the external seeds structures had not been fully formed by then.

The polyphenol contents were highest at 10 DPA and decreased to a minimum at 32 DPA onwards (Figure 6). This result agreed with that of Kennedy et al. (2000) and Ristic \& Iland (2005) who stated a decrease in phenolic compounds during the maturation process probably due to a greater activity of polyphenoloxidases.
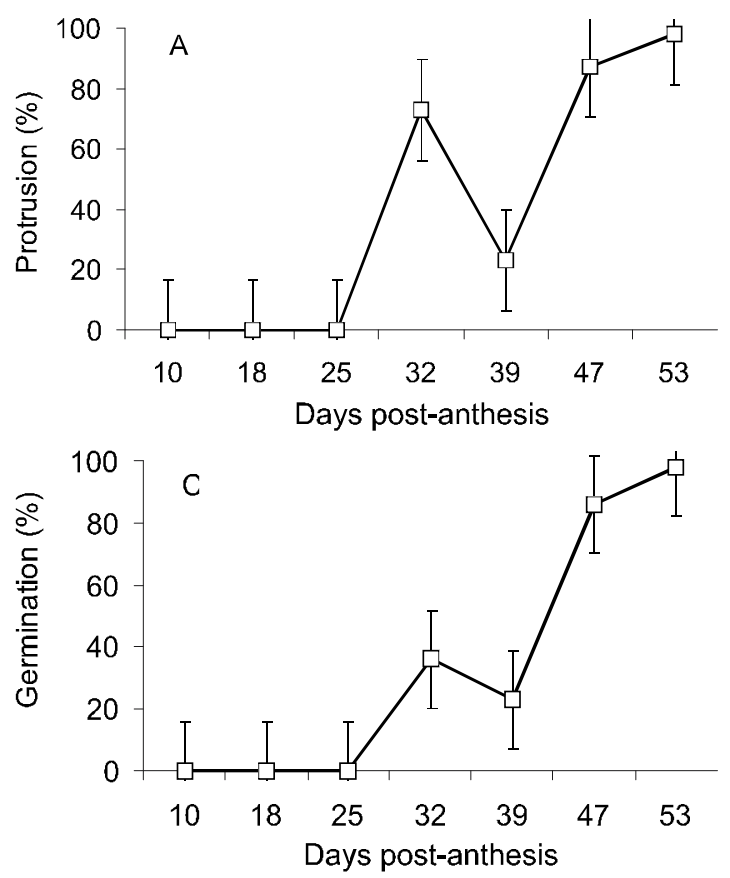

A comparison of the results of in vitro germination and polyphenol contents revealed a coincidence of lower embryo germination during the period with highest polyphenol content (Figures 4 and 6). Phenolic oxidation is one of the problems that can cause alterations in germination since these compounds may reduce oxygen availability within seeds, thereby limiting the germination process (Bewley \& Black, 1994).

The highest glucose content $(8.8 \%)$ was measured at 10 DPA, followed by a decrease until 39 DPA, after which it remained constant (Figure 7). Saccharose content showed a transient increased around 32 DPA. A temporary conversion of glucose to saccharose around this time of development is suggested. Stachyose content tended to increase slightly until 25 DPA, followed by a decrease. Raffinose was only

Table 2 - Ratio of glucose (G), saccharose (S), stachyose (E) and raffinose (R) in Tabebuia serratifolia seeds during development.

\begin{tabular}{lccc}
\hline DPA & Ratio G/S & Ratio S/E & Ratio R/S \\
\hline 10 & 0 & 0 & 0 \\
18 & 27.912 & 1.239 & 0 \\
25 & 4.863 & 1.926 & 0.032 \\
32 & 1.167 & 6.169 & 0.068 \\
39 & 2.215 & 895 & 0 \\
47 & 3.968 & 619 & 0 \\
53 & 2.801 & 3.583 & 0 \\
\hline
\end{tabular}
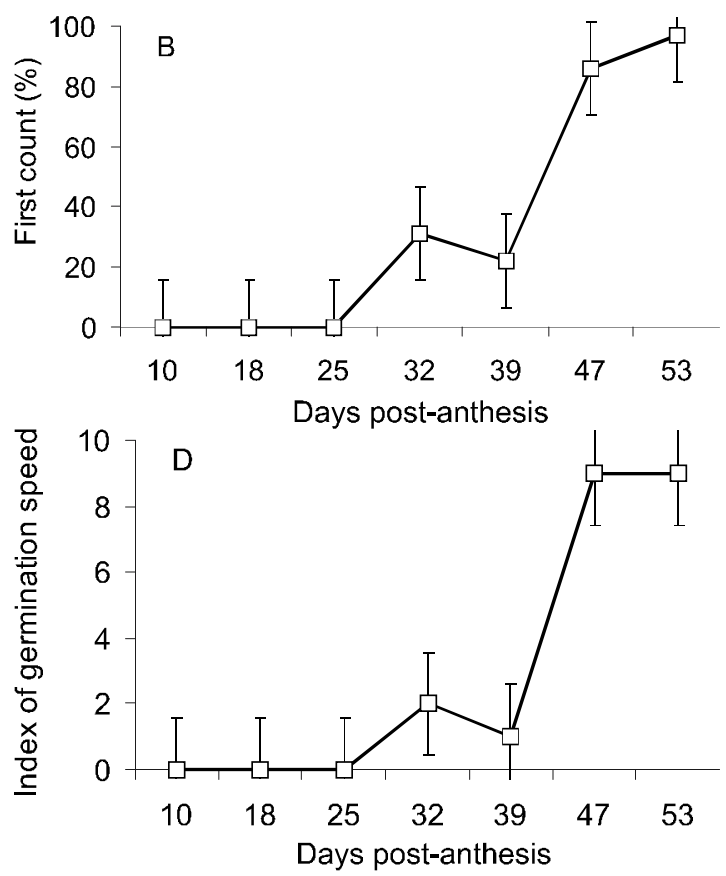

Figure 5 - Root protrusion (A), first germination count (B), final count of the germination (C) and index of germination speed (D) of Tabebuia serratifolia seed germination without surface disinfestations during development. Vertical bars indicate standard deviations. 
found in trace amounts at 25 and 32 DPA, probably in coincidence with the beginning of the maturation process. The glucose:saccharose ratio was highest at 18 DPA and lowest at 32 DPA. The saccharose:stachyose ratio was highest at 39 and 47 DPA, followed by a drastic drop at 53 DPA. The raffinose:saccharose ratio was highest at 32 DPA and lowest at 25 DPA (Table 2).

The monosaccharide levels in orthodox seeds are reduced in the last maturation stages, possibly due to the preferential formation of oligosaccharides (Vertucci \& Farrant, 1995). The reduction in the monosaccharide content results in a reduction of the respiration substrate and can entail metabolic quiescence, limiting the source of free radicals. The desiccation tolerant tissues formed during maturation are characterized by high saccharose and oligosacharide quantities (stachyose or raffinose) (Kuo et al., 1988) and by the absence (or at least low quantity) of reducing monosacharides such as galactose, mannose, glucose and fructose. However, high contents of saccharose and oligosaccharides may also be present during recalcitrant or desiccation sensitive seed development, which indicates that the ability of tolerating drought is not the consequence of the presence of oligosaccharides only (Farrant et al., 1993).

The electrophoretic profile of heat-resistant proteins (Figure 8) shows the presence of bands in $T$. serratifolia seeds at developmental stages. The absence of diagnostic bands in the upper part of the gel is evi-

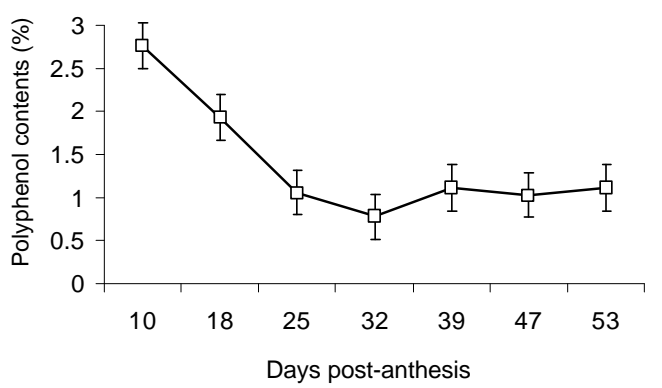

Figure 6 - Polyphenol content of Tabebuia serratifolia seeds during development,. Vertical bars indicate standard deviations. dent as compared with the control (soybean) seeds. The low molecular weight bands at around $10 \mathrm{kDa}$ altered in intensity with the advancement of maturation. The highest band intensities were observed at 25, 32 and 53 DPA and the lowest at 39 and 47 DPA. The lowest band intensity (observed at 39 DPA) was correlated with minimum reducing sugar contents. This also coincided with the attainment of highest embryo germinability by in vitro cultivation, whereas the physiological quality of $T$. serratifolia seeds increased after 39 DPA.

The heat-resistant proteins are highly watersoluble and stable even at boiling temperatures, which is attributed to the large proportion of hydrophilic amino acids, particularly glutamine and glycine (Walters et al., 1997). Furthermore, these proteins are stored in the last seed development stages, coinciding with desiccation tolerance. However, Farrant et al. (1992) found no alterations in the contents of LEA proteins in drought intolerant seeds. All these alterations at 39 DPA are indicators of the beginning of maturation (Bewley \& Black, 1994). Accumulation of reducing sugars and an increase in the intensity of heat-resistant protein bands were observed at 53 DPA, which indicates the acquisition of desiccation tolerance by the species, according to the same authors.

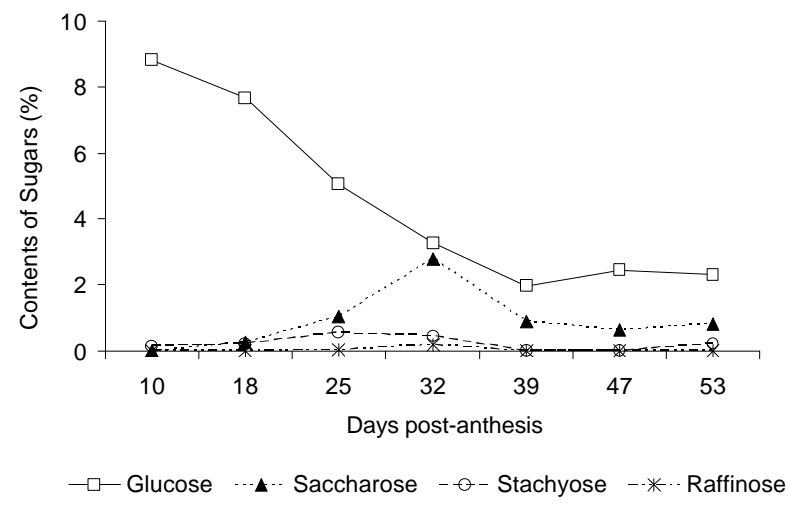

Figure 7 - Contents (\%) of glucose (G), saccharose (S), stachyose (E) and raffinose (R) in Tabebuia serratifolia seeds during development.

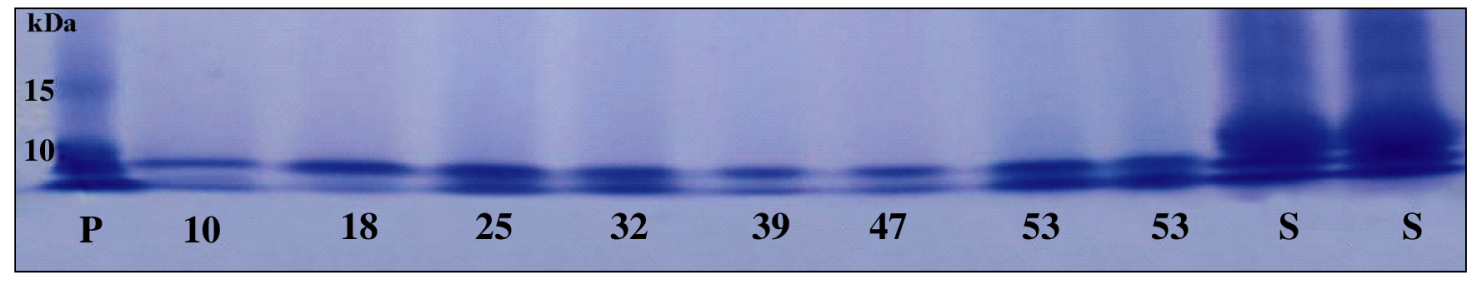

Figure 8 - Electrophoretic profile of heat-resistant proteins of Tabebuia serratifolia seeds during development, as related to the DPA (10, 18, 25, 32, 39, 47 and 53 DPA). Standard protein ladder (P) from 220 to 10kDa. Control soybean (S). 
Based on the data obtained a descriptive model of $T$. serratifolia seed development was proposed (Figure 9). Based on this model, it is possible to identify or allocate morphophysiological events in development, so that the process and mechanisms that may control development are better understood, in order to obtain quality seeds for conservation of the species. In $T$. serratifolia seed, the stage of histodifferentiation ends around 25 DPA, when seed maturation begins, which lasts until 53 DPA. The first alterations that indicate seed maturation of $T$. serratifolia occur from 39 DPA onwards, when variations in fruit and seed color and sizes, a visualization of the internal structures by radiographic analysis and increases in the moisture content, dry matter and percentage of seed and embryo germination in vitro are observed, apart from a reduction in reducing sugars and heat-resistant proteins.

The physiological maturity of $T$. serratifolia seeds is reached at $53 \mathrm{DPA}$, in coincidence with maximum dry matter accumulation, germination and index of germination speed ex vitro, besides a decrease in the polyphenol content, greater intensity of bands of heat-resistant proteins and the beginning of fruit opening.

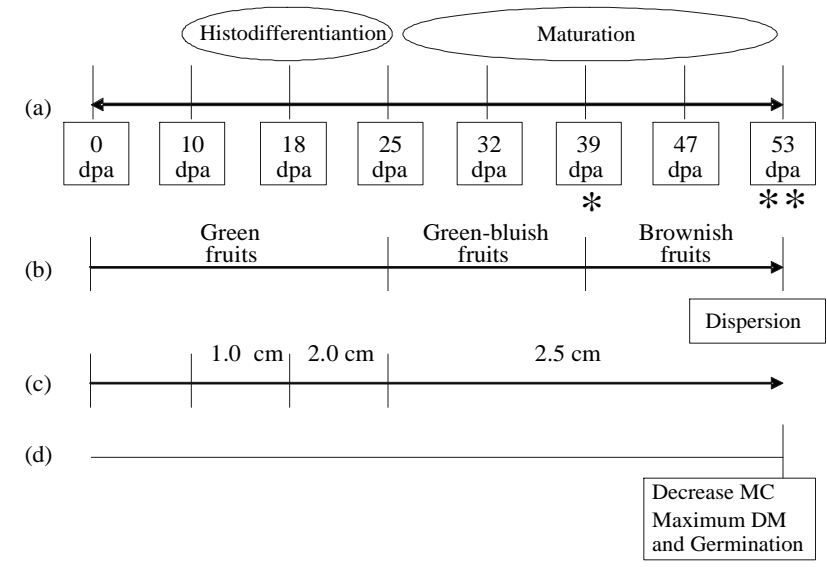

(e)

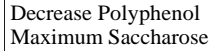

Maximum Saccharose and Stachyose

Figure 9 - Descriptive model of the Tabebuia serratifolia seed development. (a) Identification of the development stages as related to the DAP 10, 18, 25, 32, 39, 47, and 53 DPA; (b) Development as related to the fruit color; (c) Development as related to the seed size; (d) Moisture content (MC) of seeds, Dry matter (DM) of seeds and Germination; (e) Polyphenol contents, saccharose $(\mathrm{S})$ and stachyose $(\mathrm{E}) ;$ * Root elongation embryo.; ** Maximum quality seed.

\section{ACKNOWLEDGMENTS}

To CAPES and FAPEMIG by financial support and the Universidade Federal de Lavras (UFLA).

\section{REFERENCES}

AJAYI, S.A.; FAKOREDE, M.A.B. Physiological maturity effects on seed quality, seedling vigour and mature plant characteristics of maize in a tropical environment. Seed Science and Technology, v.28, p.301-319, 2000.

ALFENAS, A.C.; PETERS, I.; BRUCE, W.; PASSADOS, G. C. Eletroforese de proteínas e isoenzimas de fungos e essências florestais. Viçosa: UFV, 1991. 242p.

ASSOCIATION OF OFFICIAL ANALITICAL CHEMISTS - AOAC. Methods of the Association of Official Analytical Chemists. Washington, DC: AOAC, 1990. 684p.

ASTARITA, L.V.; FLOH, E.I.S.; HANDRO, W. Free amino acid, protein and water content changes associated with seed development in Araucaria angustifolia. Biologia Plantarum, v.47, p.53-59, 2003.

AWALE, S.; KAWAKAMI, T.; TEZUKA, Y.; UEDA, J.; TANAKA, K.; KADOTA, S. Nitric oxide (NO) production inhibitory constituents of Tabebuia avellanedae from Brazil. Chemical \& Pharmaceutical Bulletin, v.6, p.710-713, 2005.

BARBEDO, C.J.; CICERO, S.M., Effects of initial quality, low temperature and ABA on the storage of seeds of Inga uruguensis, a tropical species with recalcitrant seeds. Seed Science and Technology, v.28, p.793-808, 2000.

BARBOSA, J.M.; SANTOS, S.R.G.; BARBOSA, L.M.; SILVA, T.S.; VISCIOTTANO, W.A.; ASPERTI, L.M. Desenvolvimento floral e maturação de sementes de Tabebuia avellanedae Lorentz ex Griseb. Ecossistema, v.17, p.5-11, 1992.

BERNAL-LUGO, I.; LEOLPOLD, A.C. Changes in soluble carbohydrates during seed storage. Plant Physiology, v.98, p.1207-1210, 1992.

BEWLEY, J.D.; BLACK, M. Seeds: physiology of development and germination. 2 ed. New York: Plenum Press, 1994. 445p.

BLACKMAN, S.A.; WETTLAUFER, S.H.; OBENDORF, R.L.; LEOPOLD, A.C. Maturation proteins associated with desiccation tolerance in soybean. Plant Physiology, v.96, p.868-874, 1991.

BUITINK, J.; HOEKSTRA, O.; LEPRINCE. O. Biochemistry and biophysics of tolerance systems. In: BLACK, M.; PRITCHARD, H.W. Desiccation and survival on plants: drying without dying. Wallingford: CABI, 2002. p.293-318.

CARVAlho, N.M.; NAKAGAWA, J. Sementes: ciência, tecnologia e produção. Jaboticabal: FUNEP, 2000. 588p.

FARRANT, J.M.; PAMMENTER, N.W.; BERJAK, P. Development of the recalcitrant (homoiohydrous) seeds of Avicennia marina: Anatomical, ultrastructural and biochemical events associated with development from histodifferentiation to maturation. Annals of Botany, v.70, p.75-86, 1992.

FARRANT, J.M.; PAMMENTER, N.W.; BERJAK, P. Seed development in relation to desiccation tolerance: a comparison between desiccation-sensitive (recalcitrant) seeds of Avicennia marina and desiccation-tolerant types. Seed Science Research, v.3, p.1-13, 1993.

FIGLIOLIA, M.B.; SILVA, A.; JARDIM, D.A.P.; IWANE, M.S.S. Viabilidade de sementes liofilizadas de essências florestais nativas. Silvicultura, v.20-22, p.47-55, 1988.

GEMAQUE, R.C.R.; DAVIDE, A.C.; FARIA, J.M.R. Indicadores de maturidade fisiológica de sementes de ipê-roxo (Tabebuia impetiginosa (Marts.) Standl.). Cerne, v.8, p.87-94, 2002.

GOLDSTEIN, J.L.; WAIL, T. Changes in tannin in ripening fruits. Phytochemistry, v.2, p.371-382, 1963.

GURUSINGHE, S.; BRADFORD, K.J. Galactosyl-sucrose oligosaccharides and potential longevity of primed seeds. Seed Science Research, v.11, p.121-1333, 2001. 
HOEKSTRA, F.A.; GOLOVINA, E.A.; BUITINK, J. Mechanisms of plant desiccation tolerance. Trends in Plant Science, v.6, p.431-438, 2001.

INTERNATIONAL SEED TESTING ASSOCIATION - ISTA. International rules for seed testing. Bassersdorf: ISTA, 2004. 410p.

KAGEYAMA, P.Y.; SANCHEZ, S.P.A.; FERRAZ, E.M.; SOUZA, L.M.C. Armazenamento de sementes de três espécies nativas (Tabebuia heptaphylla, Erytrhina verna e Chorisia speciosa). Revista do Instituto Florestal, v.4, p.435-439, 1992.

KENNEDY, J.A.; TROUP, G.J.; PILBROW, J.R.; HUTTON, D.R.; HEWWITT, D.; HUNTER, C.R.; RISTIC, R.; ILAND, P.G.; JONES, G.P. Development of seed polyphenols in berries from Vitis vinifera L. cv. Shiraz. Australian Journal of Grape and Wine Research, v.6, p.244-254, 2000.

KUO, T. M.; MIDDLESWORTH, J.F. van; WOLF, W.J. Content of raffinose oligosaccharides and sucrose in various plant seeds. Journal of Agricultural and Food Chemistry, v.36, p.3236, 1988.

LEPRINCE, O.; DELTOUR, R.; THORPE, P.C.; ATHERTON, N.M.; HENDRY, G.A.F. The role of free radicals and radical processing systems in loss of desiccation tolerance in germinating maize (Zea mays L.). New Phytologist, v.116, p.573-580, 1990.

LIU, T.; BURG, W.J.; AARTSE, J.W.; ZWOL, R.A.; JALINK, H.; BINO, R.J. X-ray studied in embryo and endosperm morphology during priming and imbibitions of tomato seeds. Seed Science Research, v.3, p.171-178, 1993.

LLOYD, G.; McCOWN, B. Commercially-feasible micropropagation of mountain laurel Kalennia latifolia, by use of shoot-tip culture. International Plant Propagators' Society Combined Proceedings, v.30, p.421-427, 1980.

MAEDA, J.A.; MATTHES, L.A.F. Conservação de sementes de ipê. Bragantia, v.43, p.45-50, 1984.

MAGUIRE, J.D. Seed of germination, aid in selection and evaluation for seedling emergence and vigor. Crop Science, v.2, p.176$177,1962$.

MAI-HONG, T.; HONG, T.; HIEN, N.T.; HAI, H.; TUNG, T.D.; LE-TAM, V.; NGOC-TAM, B.; ELLIS, R.H. Seed development, maturation and storage behavior of Mimusops elengi L. New Forest, v.32, p.9-19, 2006.

MURASHIGE, T.; SKOOG, F. A revised medium for rapid growth and bioassays with tabacco tissue cultures. Physiologia Plantarum, v.15, p.473-497, 1962.

NOBRE, A.M. Qualidade sanitária e fisiológica de sementes de Ipê roxo (Tabebuia impetiginosa) e Angico vermelho (Anadenanthera macrocarpa) em função de tratamentos diferenciados de frutos e sementes. Lavras: UFLA, 1994. 73p. Tese (Doutorado).
OLIVEIRA, L.M., Avaliação da qualidade de sementes de Tabebuia serratifolia Vahl. Nich. e T. impetiginosa (Martius Ex A. P. De Candolle Standley) envelhecidas natural e artificialmente. Lavras: UFLA, 2004. 160p. Tese (Doutorado).

RISTIC, R.; ILAND, P.G. Relationships between seed and berry development of Vitis Vinifera L. cv Shiraz: developmental changes in seed morphology and phenolic composition. Australian Journal of Grape and Wine Research, v.1, p.4358,2005

RODRIGUES, R.R.; MARTINS, S.V.; BARROS, L.C. Tropical Rain Forest regeneration in an area degraded by mining in Mato Grosso State, Brazil. Forest Ecology and Management, v.190, p.323-333, 2004.

SAS INSTITUTE. SAS/STAT: user guide. 4 ed. Cary: SAS Institute, 1990.

SHAH, S.; TEWARI, B.; BISHT, S.; TEWARI, A. Seed maturation indicators in Pyracantha crenulata Roxb. In Kumaun Central Himalaya. New Forest, v.32, p.1-7, 2006.

SUN, W.; MONTAGU, M.V.; VERBRUGGEN, N. Small heat shock protein and stress tolerance in plants. Biochimica et Biophysica Acta, v. 1577, p.1-9, 2002.

TEKRONY, D.M.; HUNTER, J.L. Effect of seed maturation and genotype on seed vigor in maize. Crop Science, v.35, p.857862,1995

VERTUCCI, C.W.; FARRANT, J.M. Acquisition and loss of desiccation tolerance. In: KIGEL, J.; GALILI, G. (Ed.) Seed development and germination. New York: Marcel Dekker, 1995. p.237-271.

WALTERS, C.; RIED, J.L.; SIMMONS, M.K.W. Heat-soluble proteins extracts from wheat embryos have tightly bound sugars and unusual hydration properties. Seed Science Research. v.7, p.125-134, 1997.

WANG, X.F.; FU, J.K. Characteristics of development and maturation of Mangifera indica fruits and seeds. Plant Physiology Communications, v.2, p.112-113, 1991.

WISE, M.J. Leaping to conclusions: a computational reanalysis of late embryogenesis abundant proteins and their possible roles. BMC Bioinformatics, v.4, p.52, 2003.

Received August 17, 2007

Accepted March 13, 2008 